UDC: 811.111'243; 371.3::811.111(497.7)

\title{
THE ISSUE OF AGE AND LANGUAGE TRANSFER IN SECOND LANGUAGE ACQUISITION
}

\author{
ANA LAZAROVA-NIKOVSKA ${ }^{1}$ \\ Faculty of Foreign Languages, \\ FON University, Skopje, \\ Republic of Macedonia
}

Cilj ovog rada jeste da doprinese novim saznanjima o usvajanja drugog jezika tako što će ispitati uticaj starosti na početne faze razvoja drugog jezika (L2) u pogledu transfera morfosintaksičkih odlika iz maternjeg jezika. U radu se koristi generativni okvir usvajanja jezika, u kome je direktno poređenje usvajanja L2 kod dece i odraslih nedovoljno istražena oblast. U radu se ispituje parametar univerzalne gramatike [ \pm jak] fleksija, a naročito podizanje glagola (eng. V-raising), budući da ima različite vrednosti u engleskom [- jak] i makedonskom [+ jak]. Ispitanici su jedna grupa dece (od 8 do 11 godina starosti) i jedna grupa odraslih (od 20 do 60 godina). Svi ispitanici su izvorni govornici makedonskog na početnom stepenu razvoja engleskog kao drugog jezika, a testirani su nakon četiri nedelje izloženosti posebno osmišljenim smernicama vezanim za podizanje glagola u engleskom. Budući da dolazi do transfera čitave gramatike prvog jezika (L1), rezultati idu u prilog tzv. hipotezi očuvanja (eng. Conservation Hypothesis) kod transfera iz L1 u početnim fazama usvajanja drugog jezika (Van de Craats i dr. 1999).

Ključne reči: uticaj starosti, jezički transfer, početne faze, usvajanje engleskog kao drugog jezika, podizanje glagola (V-raising).

\section{INTRODUCTION}

One of the differences between first and second language acquisition (L2A) is that the latter necessarily implies knowledge of a previously learnt language, i.e. at least of the mother tongue (L1). Language transfer, both from the native language and from other previously learnt languages, can affect each stage of the $L 2$ developmental process. The transfer phenomenon is particularly important for the description of the initial state of

1 Kontakt podaci (Email): analazarovanikovska@gmail.com 
L2A, a developmental period of interest to the current paper. The degree of $\mathrm{L} 1$ transfer attested in numerous studies varies depending on a number of variables, such as the language domain tested, the developmental stages investigated, and the age of the learner, among others. The existing transfer theories do not make explicit predictions about any age differences with respect to the phenomenon of language interference. Empirical evidence exists, however, as $\mathrm{L} 1$ transfer has been separately reported in the initial stages of both children (e.g. Haznedar 1997) and adults (e.g. Parodi et al. 2004). The two age groups have not been directly compared. The current study overcomes this limitation by comparing a group of children and a group of adults, while holding the L 1 language and the $\mathrm{L} 2$ input constant, as two very relevant variables for the validity of the results. The study bears both theoretical significances concerning the age factor in $L 2 A$, as well as methodological implications with respect to the expectations teachers can have from different age groups in the process of $L 2$ instruction. Although we are aware of the formal distinction made throughout the literature between second language acquisition and foreign language acquisition/learning (e.g. Krashen 1982), the two terms and the abbreviation L2A will be used synonymously throughout the article. However, we would like to be precise and explain that the experimental context of the current study refers to $\mathrm{L} 2$ learning in a classroom setting (i.e. foreign language learning).

\section{THE INITIAL STAGES AND L1 TRANSFER - A GENERATIVE PERSPECTIVE}

In the generative framework, L1 transfer is regarded as part of the learner's grammatical competence, rather than as a strategy consciously employed in the process of $L 2 A$. Among the researchers arguing for the involvement of Universal Grammar (UG) in $\mathrm{L} 2 \mathrm{~A}$, two broad theories exist concerning the question of $\mathrm{L} 1$ transfer: those advocating no L1 transfer (e.g. Platzack 1996) and those assuming the presence of L1 transfer (e.g. Eubank 1994). Empirical evidence for L1 transfer in the generative framework of L2A usually derives from the studies testing the acquisition of UG parameters, for example Hilles (1986), Tsimpli and Roussou (1991), Phinney (1987) for the Pro-drop parameter. Transfer effects have also been observed in the acquisition of various other morphosyntactic phenomena, for example, in the L2A of German by adult Romance, Korean and Turkish speakers, Parodi et al. (2004) found a great influence of the native language in the acquisition of target-like morphosyntax on nominals.

The L2 learner's starting point has become the focus of much investigation and debate in recent years as it may be considered diagnostic for the nature of the subsequent developmental stages, as well as for the ultimate attainment in L2A (Meisel 2000). Lack of sufficient $L 2$ input and the short time of $L 2$ exposure may encourage the learner to use their $\mathrm{L} 1 \mathrm{structural}$ representation (to a greater or lesser extent). The three main perspectives on $\mathrm{L} 1$ transfer in the initial stages of L2A can be labelled as follows: Full Transfer Hypothesis (Hawkins/Chan 1997), No Transfer Hypothesis (e.g. Epstein et al. 1996), and Partial Transfer Hypothesis (Vainikka/Young-Scholten 1994).

Assuming that L1 plays some role in L2A (Full or Partial transfer), there are three main theories of the $\mathrm{L} 2$ initial state, which differ regarding the claims for the exact 
involvement of the mother tongue in the process of L2A: The Minimal Trees Hypothesis - only the L1 properties of lexical, but not of functional categories transfer (Vainikka/ Young-Scholten 1994); The Valueless Features Hypothesis - the strength of the features associated with functional categories does not transfer (Eubank 1994) and the Full Transfer Hypothesis - the whole structure of L1 transfers (Schwartz/Sprouse 1994). An even more detailed variation of the Full Transfer Hypothesis is the Conservation Hypothesis (Van de Craats et al. 1999). These authors prefer the term 'conservation' to 'transfer', as they understand the initial state of L2A as conservation of existing L1 knowledge. The language elements they believe are conserved in the initial stages of L2A are the following: a) parameter settings (strength values, headedness); b) knowledge of lexical items (formal features, categorial values, and semantic-conceptual values); c) knowledge of morphology and morphological realisation rules (e.g. realisation of case) and d) pragmatic knowledge of information-related grammatical encodings. Van de Craats et al. (Ibid.) argue that $\mathrm{L} 2$ phonological matrices are matched with $\mathrm{L} 1$ semantics and L1 formal features.

On the one hand, all the transfer assuming theories stated above differ in their predictions about the precise involvement of the mother tongue at the commencement of L2A. On the other hand, what they all have in common is that they do not make explicit predictions about any age differences in L1 transfer.

\section{AGE AND L1 TRANSFER}

Research on L1 transfer has mostly focused on the adult population of second language learners, with the majority of studies providing evidence of transfer effects with this group of learners. Such findings are compatible with general intuition and practical experience of $L 2$ learning. One of the reasons for the lack of research on child L2A in L1 transfer has been the assumption that child L2A is similar to child L1A (e.g. Herschensohn 2000). The assumption is based on the fact that children are generally more successful than adults with regard to the ultimate attainment in L2A. This view has been encapsulated in two hypotheses on the age issue in language acquisition, Position A, [Child L1 = Child L2 $\neq$ Adult L2] (compatible with the No Access and Partial Access to UG Hypotheses for L2A, e.g. Bley-Vroman 1989), Hawkins and (han 1997) and Position B, [Child L1 = Child L2 = Adult L2] (analogous to the Full Access to UG Hypothesis, e.g. Epstein et al. 1996). Compatible with their argument is the belief that L2A during the critical period should show little or no effect of transfer from the first language because direct access to UG in this period should override any cognitive intervention in the process of constructing the system of rules for the second language. On the other hand, a different view on L1 transfer with $\mathrm{L} 2$ children can be deduced from the postulations of the Asymmetric Acquisition Hypothesis (AAH) for the L2 development (Schwartz 2003), which we can represent by the following summary: [Child L1A $\neq$ (Child L2A = Adult L2A) for syntax] and [(Child L1A similar to Child L2A) $\neq$ Adult L2A) for morphology]. In other words, in the syntactic $L 2$ development, at least in the early and intermediate stages, it is assumed that both groups of $\mathrm{L} 2$ learners can be equally affected by the mother tongue influence, since both groups are expected to re-set the 
parameters from the $L 1$ to the $L 2$ value, where the two values differ. For example, both Macedonian child and adult L2 acquirers of English need to learn that English is a [- Prodrop] language (Chomsky 1981) and therefore grammatical subjects cannot be omitted in the sentence, whereas they can in Macedonian because it has a different value of the same UG parameter a [+ Pro-drop]. The following pair of sentences illustrates the point: English: I want to eat (subject + verb). Macedonian: Сакам да јадам (verb inflected for person, subject omitted).

In the morphological L2 development, it is difficult to conclude what the view on transfer is, as the study on which the AAH generalisation is based included learners from different native language backgrounds and did not test for L1 transfer. However, based on the hypothesis that $\mathrm{L} 1$ and $\mathrm{L} 2$ children make similar morphological errors, the implication is that transfer is not expected with $L 2$ children in the domain of L2 morphology, or it is less prominent and of a temporary nature, in comparison to morphological transfer effects expected among the adult $\mathrm{L} 2$ learners.

Although research on $\mathrm{L} 1$ transfer with children is rare, the prevailing evidence seems to offer support for the view that child L2A is not entirely identical to child L1A, primarily due to the native language influence with the former group of learners (White 1990/91; Lakshmanan 1991; Haznedar 1997; Unsworth 2002b). In the longitudinal study of naturalistic child L2 acquisition of English conducted by Haznedar (1997), it is interesting that the child switched to the English value of lexical and functional headedness in the fourth month of recording, consistently producing target-like utterances thereafter. As Schwartz (2003:31) points out, transfer effects in early child L2A can be very fleeting and difficult to catch. The implication may be that pre-puberty L2 learners grow out of L1 transfer quickly and (perhaps) permanently, while traces of the L1 structure remain in the interlanguage of adult L2 learners (perhaps) throughout all stages of development, eventually resulting in different levels of ultimate attainment between the two age groups.

The exact relation between age and transfer is still far from clear (0dlin 1993: 152) and researchers advocate the idea that different types of transfer before and after the closure of the critical period would serve to support the argument for a critical period in L2A (Bialystok and Hakuta 1999:167). L2 children and adults have not been directly compared on the issue of initial L1 transfer. However, based on the independentempirical work which reports $\mathrm{L} 1$ transfer effects both with $\mathrm{L} 2$ children and with L2 adults and assuming that L1A is a different process from L2A, I hypothesise in this paper that both age groups will comply with the predictions of the Conservation Hypothesis, thereby preserving all L1 morphosyntactic features in their early interlanguage grammar.

\section{THE EXPERIMENT}

For the purposes of analysing the age effect of transfer in the initial stages of L2A, new data was gathered from an experimental setting in which a group of 30 children (age 8-11) and a group of 30 adults (age 20-60), all beginners of English and native speakers of Macedonian, underwent four weeks of intensive instruction on Verb raising in English. Based on a questionnaire which the participants had completed before 
the beginning of the project, there was a good balance between males, females, and different social backgrounds. In respect to levels of formal education, all subjects in the adult group had obtained either high school diplomas or higher education degrees. Moreover, all (but 8) were employed in an intellectually, rather than physically, demanding job. of the remaining eight, four were students, one was unemployed, one was a manual worker and two were retired.

The participants were recruited on the basis of a public announcement in a daily newspaper. They were all volunteers, hence motivated to take part in the project. All participants were beginners of English as none of them had had a formal tuition in English prior to the experiment nor was naturalistically exposed to the target language. Nevertheless, I acknowledge the inevitable fact that all the participants have had some contact with English, mainly via the media (TV and radio). An informal conversation with each participant carried out at the beginning of the project, indicated that, despite the limited informal exposure to English, participants' knowledge of the language consisted of no more than a few words or phrases, such as 'yes', 'no', 'hello', 'thank you', and none of them was familiar with the grammatical elements subject of investigation.

As the closure of the critical period for morphosyntax is believed to be around the age of 15 (Long 1990), the age range of the children group (8-11) taking part in this experiment is considered to be within the limits of the critical period for morphosyntax. Moreover, the practical arguments for choosing this particular age group of children are based on two premises: a) Macedonian children start learning the Latin alphabet at the age of 8, which was a necessary background knowledge for the written tests in English used in the experiment, and b) after the age of 7.5, children are able to make grammaticality judgments on sentences and the task is not experienced as cognitively too demanding (Slavoff and Johnson 1995).

The instruction took place twice a week between 21 May and 29 June 2001 in Skopje, Republic of Macedonia and each age group was further divided in two subgroups in order to reduce the number of students in the classes and thus increase instruction efficiency. The adult group was also divided based on the variations in age, i.e. a subgroup of 20-40-year olds and a subgroup of 40-60-year olds.

A common criticism for most of the studies focusing on the theories of the initial state is that the interlanguage stage they consider as initial does not really represent an early enough period of $L 2 A$, since the exposure to $L 2$ has ranged from a few months to about a whole year. In the present study, the $L 2$ learners are tested in the earliest period of L2 development, namely after four weeks of instruction in the target language. In order to strengthen the validity of the results, important experimental variables such as the time of (formal) exposure, as well as amount and type of the L2 input were strictly controlled in the current study.

The teaching methodology was explicit instruction of theoretically chosen functional elements in English, within the context of meaningful lexical topics, embedded in carefully and specifically prepared teaching materials. Metalanguage was avoided in the presentation of grammar: rather, the $L 2$ grammatical elements were introduced by emphasising the main points both visually and orally. Moreover, there was no explicit negative evidence during the instruction period, i.e. students were never told why the non target-like answers they provided were incorrect in L2. Instead, 
the correct answer was repeated. One of the reasons for the use of positive evidence is rooted in our assumption that by not giving participants explicit negative evidence, they would have the possibility to express their readiness to rely on L1 while making grammatical judgments for $\mathrm{L} 2$, rather than simply to memorise the information (rules) given in the explicit negative evidence about what is not allowed in L2. Efforts were made to maintain the amount of relevant input and relevant practice at a constant level between the groups. This was achieved by presenting both age groups with texts that contained the same amount of testing structures as well as the same amount and type of exercises to practice each structure. The fact that the adults are usually faster readers and, therefore, usually cover the relevant material more quickly during class, was accounted for by introducing more vocabulary with this group of learners throughout the period of instruction. This additional vocabulary material did not contain any grammar and was meant to be a 'time-filler'. Examples of that material included texts introducing the 'days of the week', 'months of the year', etc. Therefore, the groups inevitably differed only in the size of vocabulary and the lexical topics covered (e.g. office versus school), which were accommodated to the age of the subjects in order to attract their attention and maintain their interest. However, with respect to the type and amount of relevant grammar taught and practiced, the two age groups were as identical as possible.

In this paper, the age differences in the early stages of L2A are investigated using the Principles and Parameters Theory (PPT) of UG as its grammatical framework. According to this theory, UG principles are shared by all human languages. UG parameters, on the other hand, express language specific properties and are assumed to have binary values ( + ) and (-). Particular attention is paid to verb raising (V-raising/ movement), a grammatical phenomenon deriving from the $[ \pm$ strong Infl] parameter and evidenced in the surface structure of negative (IP domain) and interrogative sentences (CP domain) (Pollock 1989; Iatridou 1990). Macedonian and English have different values of this parameter and therefore the learners are faced with the task of restructuring their L1 grammar (Macedonian [+ strong Infl]/[+ V-raising]) to fit the value of the L2 language (English [- strong Infl]/[- V-raising]). For example, Macedonian learners of English needed to learn that lexical verbs cannot precede the grammatical subject in interrogative sentences, they are not 'strong' enough to move to the higher structural nodes in the sentence, hence 'do-support' is needed. In Macedonian, V-raising is possible, for example: English: *Know you how to play the piano? vs. Macedonian: Знаеш ли да свириш на клавир?.

Two types of tests were administered at the end of the instruction period: a written Grammaticality Judgment Test on L2 syntax and a Fill in the Gap written test on L2 morphology. The syntactic task examined learners' knowledge of V-raising in English, as evidenced in negative sentences (IP domain) and in interrogative sentences (CP domain). The morphological task was employed to test learners' knowledge of correct person/number verbal agreement. L2 syntax and morphology were presented and tested using the following verb types: copula be, modal can and lexical verbs (hence, do-support).

In order to make the testing procedure as accommodating to the child learners as possible, the following measures were incorporated into the study: a) the tests were 
unpaced; $b$ ) the instructions were written and read in the learners' $L 1 ; c)$ the participants were familiar with the exact words used in the instructions to the testing tasks because they were practiced during the teaching period through various grammatical exercises (however, different lexical items were used for the final tests in order to avoid the possibility of a sentence being learnt by heart).

In the following section, only the analyses from the perspective of overall L1 transfer are presented, where overall syntactic transfer is defined as transfer of the IP and the CP domain in total, whereas the morphological transfer is tested using the L1like overt finite features on the modals. The results for the learners' progress with $\mathrm{L} 2$ syntax and morphology are not considered on this occasion.

\section{RESULTS AND DISCUSSION}

Using a Grammaticality Judgment Test, the learners were asked to judge each sentence as grammatical in the target-like language, i.e. determine whether it was correct in English or not. They were not told that some of the sentences were L2-like, others L1-like. Therefore, in order to calculate learners' transfer errors in the initial stages of L2A, we analysed their judgments on the L1-like test sentences for each language element (verb types: be, can, main verb; domains: IP and (P), taking into consideration only those answers where the learners incorrectly accepted the L1-like sentences as grammatical in L2. Since English and Macedonian have different values of the [ \pm strong Infl] parameter, a higher score in this test was, in fact, a negative one as it indicated more transfer from L1. In Figure 1 below, the two groups are compared on their overall L1 transfer. The instructions to the Grammaticality Judgment Test for syntax read as follows: Judge each of the following sentences as correct in English or not. From the answers, choose a) if you think it is correct in English; b) if you are not sure or don't know or c) if you think the sentence is not correct in English. For example:
a) My name not is Tom.
a) correct
b) don't know
c) incorrect

In order to register learners' transfer errors in the IP domain, a mark was given for each incorrectly accepted L1-like test sentence with preverbal negation for each verb type tested.

Examples 1-3 below illustrate a test sentence with each of the verb types tested:

(1) *My friends not play tennis. (Моите пријатели не играaт тенис.)

(2) *My telephone number not is 121-121. (Мојот телефонски број не е 121-121.)

(3) *My brother not can ride a bike. (Мојот брат не може да вози велосипед.)

In the CP domain, a mark was given for each incorrectly accepted L1-like test sentence with a raised main verb to a comp or Foc position (4), as well as for each L1-like sentence where the complementiser position was filled either with do or does, while a copula verb (5) or a modal (6) was situated in the Infl or Foc position of the same sentence. All three types of sentences exemplified below are an indication of 
Macedonian CP representation: in the case of V-to-C movement, it is a transfer of the parametric value, in the case of a filled Comp, it is a misanalysis of do/does as a nonverbal element, perhaps as the Macedonian question-particle dali.

Consider examples 4-6:

(4) *ike you green colour? (Сакаш зелена боја?)

(5) *Does your house is in Ohrid? (Дали твојата куќa е во 0хрид?)

(6) *Do can play the children football? (Дали можат да играат децата фудбал?)

There were 15 L1-like sentences in each domain (IP and (P), hence a total of 30 sentences in which learners' L1 transfer was tested (IP\&CP Total). The results are presented in Figure 1 below and analysed using non-parametric tests. The two age groups are presented on the $X$-axis. The results are presented on the $Y$-axes: the primary $Y$-axis (left) displays the mean score, while the secondary $Y$-axis (right) displays the same result expressed in percentages. The highest number on the primary $Y$-axis indicates the total number of test sentences for the relevant language domain.

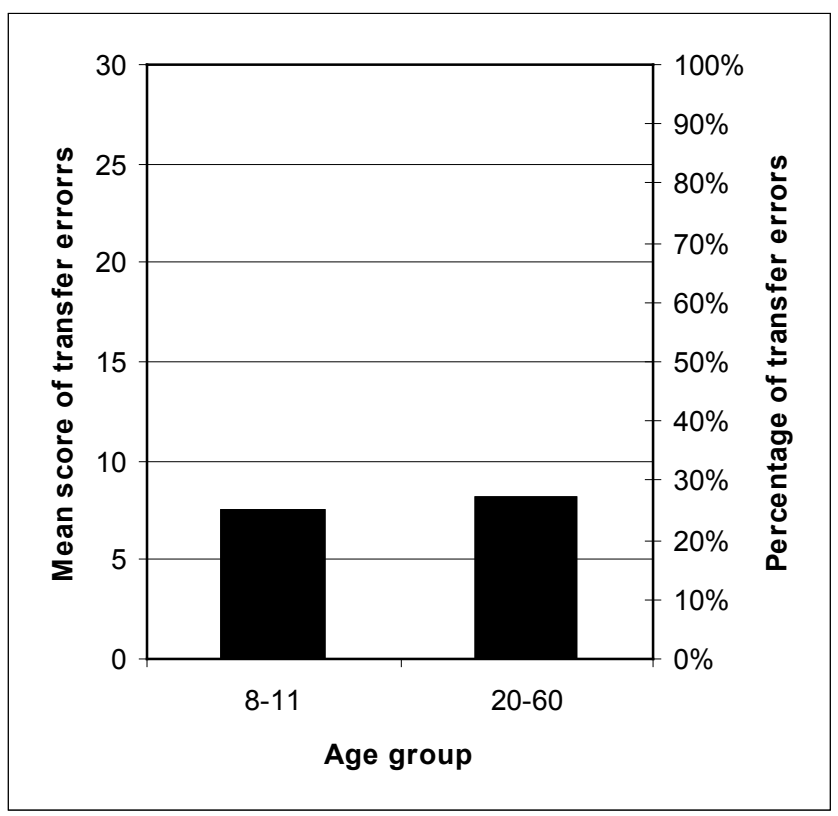

Figure 1: L1 transfer in IP\&CP Total

Regarding the general question of presence or absence of $L 1$ transfer in the initial stages of these learners, the results displayed in Figure 1 offer support for the hypothesis that L1 transfer is part of the early L2 grammar. Although there is a relatively small percentage of $\mathrm{L} 1$ transfer ( $25 \%$ for the children and $27 \%$ for the adults), it is nevertheless present in the data of these learners. Such an account of the $L 2$ initial state, where target-like representations are the dominant, yet not the only property of the 
interlanguage grammar, is also recorded in Parodi et al. (2004). In their study on word order in the nominal domain, the authors found that the L1 effects (20\%) alternate with L2 properties (80\%) in the interlanguage of the Romance L2 learners of German. Similarly, Rast (1999) observed a substantial influence of the L2 input (in comparison to the L1 grammar) in the initial stages of L2A. In the current study, the considerable effect of the target language in grammar restructuring may have been encouraged by the intensive instruction, with emphasis on the tested language domains. Nevertheless, the results also indicate that the learners did not initially override L1 transfer, even if the transfer percentage was small. Bearing in mind that the L1 value of the parameter presupposes (overt) V-raising, the current findings disprove Platzack's Initial Hypothesis of Syntax (1996), which maintained that only weak features (no movement) are present at the commencement of L2A: L1 transfer in the interlanguage of these learners implies overt movement of a functional element, i.e. a strong feature. Hence, the L1 feature strength is conserved by the tested learners, compatible with the first prediction of the Conservation Hypothesis (the Full Transfer Hypothesis). L1 acquirers of English never wrongly assume that main verbs can raise from the VP in this language, and therefore never produce questions with subject and main verb inversion (e.g. Goodluck 1991). Therefore, the results of the current study imply that the process of $L 1 A$ is not identical either with child or adult L2A, with respect to the syntactic development.

Due to space limitations, we cannot present the transfer results for the second feature predicted by this hypothesis, i.e. L1 transfer of formal knowledge of lexical items. It will suffice to say that both age groups showed similar L1 transfer in this category: slight differences, albeit not statistically different, existed between the two age groups, depending on the specific lexical item tested.

The last type of transfer prediction to be discussed in this section is knowledge of morphological realisation rules. Clearly, this does not imply that the actual phonological realisations of agreement and number were expected to transfer, rather the awareness for overt inflection. The best way to test whether Macedonian learners of English transfer this awareness is through the instances of overgeneralisation. Namely, in Macedonian the modal moze (can) inflects like a main verb. Therefore, Macedonian learners of English may misanalyse can as a main verb and make a transfer error of inflecting can with the third person singular [-s].

Consider the following example:

\section{(7) * Kaja cans speak Chinese.}

L2 learners' knowledge of verbal morphology was tested using a written Multiple Choice Test of the Fill in the Blank type. There were 9 sentences in this test, with the finite verb in each of them being deleted and substituted by a blank line. All the sentences were semantically connected to represent a letter written to an English pen friend. This was done in order to make the whole task more readable. There were three sentences testing learners' morphological knowledge of English person/ number agreement for each of the relevant verb types (be, can, main verb). Beneath each sentence, students were provided with the choice of three possible answers. They were told in the instructions for the test that only one of the three answers was target-like and therefore 
they should choose one answer they deemed was the correct form of the missing verb for the particular sentence. The exact instruction used for this test type read as follows: Fill in the blanks in each sentence with the correct answer a), b) or c) from the choices underneath. Only one of the three choices offered is the correct one in English.

Hello,

My name is Toni.

1. I ----- a student.
a) is
b) am
c) has

2. Jana my sister.
a) is
b) are
c) am

etc.

There were three sentences in the tests where learners could overgeneralise and the results are presented in Figure 2.

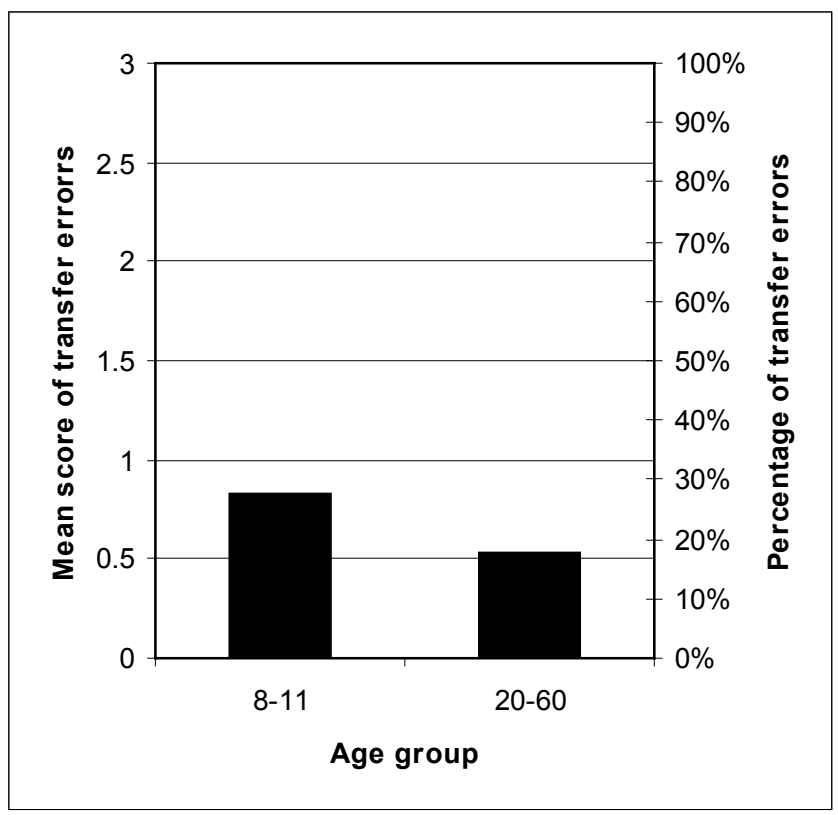

Figure 2: L1 transfer of knowledge of Morphology (3sg -s on can)

A Mann-Whitney was conducted to test the difference between the children and the adults on overgeneralisation of $[-s]$ and indicated a non-significant result $(Z=-1.026$, $p=.305$ ). Nevertheless, it emerges from Figure 2 that the L 2 children show a greater tendency for morphological transfer (27.6\% of transfer errors) in comparison to the L2 adults (17.6\%). This difference may imply that the children are more able to notice affixes as separate forms in the $L 2$ input and learn the agreement values of the inflectional affix $[-s]$. If this is true, then higher target-like scores on inflectional morphology should also be expected with this group of learners as they may find it easier to supply [-s] on L2 
lexical verbs in the obligatory contexts. With respect to comparing L1A with L2A, L1 learners of English never overgeneralise [-s] on modals (Stromswold 1990), while the results of the current study indicate that both child and adult $\mathrm{L} 2$ learners make the same overgeneralising error, thus suggesting that the morphological developments in $\mathrm{L} 1 \mathrm{~A}$ and L2A are not identical processes. With respect to the Asymmetric Acquisition Hypothesis mentioned in Section 3, the implications from the current study are inconclusive: on the one hand, the L2 children and adults have similar results on both syntactic and morphological transfer, thus not showing any asymmetry, on the other, the offered explanation for the slight increase in morphological transfer with the group of children may actually lend support for the AAH. Indeed, the AAH is a hypothesis concerning the developmental process focusing on the L2-like competence, rather than on the L1 conservation in the interlanguage data, hence the analogy is only speculative.

\section{CONCLUSIONS}

To conclude, according to the quantitative analysis presented in this paper, transfer of the entire L1 grammar appears to be part of the early stages of L2A, hence supporting the predictions of the Conservation Hypothesis. Moreover, the results indicate that the L2 children and adults are statistically similar in overall syntactic and morphological L1 transfer and different in the language learning process from L1 learners of English. Nevertheless, the minor differences between the two age groups imply that the L2 children and adults are not entirely identical in their conservation of the L1 knowledge. Such differences entail different tendencies of $L 1$ transfer with the two age groups.

Concerning the methodological implications of the presented results, we may conclude that the teachers can expect to observe L1 transfer even with young language learners (of the age range presented in this study) and such observation should be considered a natural phenomenon in the $L 2$ interlanguage data, especially in formal $\mathrm{L} 2$ learning settings. However, the small amount of $\mathrm{L} 1$ transfer recorded in the current test results suggests that intensive instruction in the L2 (and minimal use of the L1 in class) can override the effects of L1 transfer, or at least deduce them to a smaller percentage in the output of the learners. In addition, both the slight discrepancy between the child and adult L2 groups in the morphological transfer analysis, as well as similar discrepancies detected in the L2 initial development of these learners, but not presented in the current paper, lead to the observation that L2 children are more able to notice and correctly analyse details in the language, including affixes. Such observational skills should be exploited in class by the teachers by ensuring that the child L2 learners receive plenty of (meaningful) focus on inflections during the early years. The natural focus on detail may be an advantage for the $L 2$ children and may also be a contributing factor to the fact that children grow out of the L1 transfer phase more quickly, in comparison to the adult group. The experimental setting of the presented study leads to a further observation, with potential methodological implications, namely L2 children can master much more L2 material than they are usually presented with in foreign learning contexts and textbooks designed for that foreign language learning population. 


\section{REFERENCES}

Bialystok, E. and K. Hakuta. 1999. Confounded age: linguistic and cognitive factors in age differences for second language acquisition. In D. Birdsong (ed.) Second Language Acquisition and the Critical Period Hypothesis. Mahwah, NJ: Erlbaum, 161-81.

Bley-Vroman, R. 1989. What is the logical problem of foreign language learning?. In S. M. Gass and J. Schachter (eds.) Linguistic Perspectives on Second Language Acquisition. Cambridge: (UP, 41-68.

Chomsky, N. 1981. Lectures on Government and Binding. Dordrecht: Foris.

Epstein, S., S. Flynn and G. Martohardjono. 1996. Second language acquisition: Theoretical and experimental issues in contemporary research. Brain and Behavioral Sciences $19,677-758$.

Eubank, L. 1994. Optionality and the initial state in L2 development. In T. Hoekstra and B. D. Schwartz (eds.) Language Acquisition Studies in Generative Grammar. Amsterdam: John Benjamins, 369-88.

Goodluck, H. 1991. Language Acquisition. A Linguistic Introduction. Oxford: Basil Blackwell Ltd.

Hawkins, R. and Y-H. C. Chan. 1997. The partial availability of universal grammar in second language acquisition: The 'failed functional features hypothesis'. Second Language Research 13/3, 187-226.

Haznedar, B. 1997. L2 acquisition by a Turkish-speaking child: Evidence for L1 influence. In E. Hughes, M. Hughes and A. Greenhill (eds.) Proceedings of the $21^{\text {st }}$ Annual Boston University Conference on Language Development. Somerville, MA: Cascadilla Press, 245-56.

Herschensohn, J. 2000. The Second Time Round: Minimalism and L2 Acquisition. Amsterdam: John Benjamins.

Hilles, S. 1986. Interlanguage and the pro-drop parameter. Second Language Research 2: 33-52.

Iatridou, S. 1990. About Agr(p). Linguistic Inquiry 21: 551-77.

Krashen, S. D. 1982. Principles and Practice in Second Language Acquisition. Hemel Hamstead, Hertfordshire: Prentice Hall International.

Lakshmanan, U. 1991. Morphological uniformity and null subjects in child second language acquisition. In L. Eubank (ed.) Point Counterpoint. Universal Grammar in Second Language Acquisition. Amsterdam: John Benjamins, 389-418.

Long, M. 1990. Maturational constraints on language development. Studies in Second Language Acquisition 12, 251-85.

Meisel, J. M. 2000. On transfer at the initial state of L2 acquisition. Arbeiten zur Mehrsprachigkeit (Working Papers in Multilingualism) 1, 2-23.

Odlin, T. 1993. Language Transfer: Cross-linguistic influence in language learning. Cambridge: CUP.

Parodi, T., B. D. Schwartz and H. Clahsen. 2004. On the L2 acquisition of the morphosyntax of German nominals. Linguistics 42/3, 669-705.

Phinney, M. 1987. The pro-drop parameter in second language acquisition. In T. Rroeper and E. Williams (eds.) Parameter Setting. Dordrecht: Reidel, 221-38. 
Platzack, C. 1996. The initial hypothesis of syntax: A minimalist perspective on language acquisition and attrition. In H. Clahsen (ed.) Generative Perspectives on Language Acquisition: Empirical Findings, Theoretical Considerations, Crosslinguistic Comparisons. Amsterdam: John Bejamins, 369-414.

Pollock, J-Y. 1989. Verb movement, UG and the structure of IP. Linguistic Inquiry 20, 365424.

Rast, R. 1999. The first hours of second language acquisition. Acquisition et Interaction en Langue Étrangère 2, 73-87.

Schwartz, B. D. 2003. Child L2 acquisition: Paving the way. In B. Beachley, et al. (eds.) Proceedings of the $27^{\text {th }}$ Annual Boston University Conference on Language Development. Somerville, MA: Cascadilla Press, 26-50.

Schwartz, B. D. and R. Sprouse. 1994. Word order and nominative case in non-native language acquisition: A longitudinal study of (L1 Turkish) German interlanguage. In T. Hoekstra and B. D. Schwartz (eds.) Language Acquisition Studies in Generative Grammar. Amsterdam: John Benjamins, 317-68.

Slavoff, R. G. and J.S. Johnson. 1995. The Effects of Age on the Rate of Learning a Second Language. Studies in Second Language Acquisition 17, 1-16.

Stromswold, K. 1990. Learnability and the Acquisition of Auxiliaries. Unpublished PhD thesis, Massachusetts Institute of Technology.

Tsimpli, I-M. and A. Roussou. 1991. Parameter resetting in L2? UCL Working Papers in Linguistics 3, 149-69.

Unsworth, S. 2002b. Young (and older) L2 learners and Dutch scrambling. In M. Cazzoli-Goeta, S. Pourcel and L. Van Espen (eds.) Proceedings of the Fifth Durham Postgraduate Conference in Theoretical and Applied Linguistics. Durham: School of Linguistics and Language, 205-14.

Vainikka, A. and M. Young-Scholten. 1994. Direct access to X'- theory: Evidence from Korean and Turkish adults learning German. In T. Hoekstra and B. D. Schwartz (eds.) Language Acquisition Studies in Generative Grammar. Amsterdam: John Benjamins, 265-316.

Van de Craats, I., N. Corver and R. Van Hout. 1999. The Conservation Hypothesis: The initial state revisited. Acquisition et Interaction en Langue Étrangère 2, 103-17.

White, L. 1990/1991. The verb movement parameter in second language acquisition. Language Acquisition 1, 337-60.

\section{SUMMARY}

\section{THE ISSUE OF AGE AND LANGUAGE TRANSFER IN SECOND LANGUAGE ACQUISITION}

The purpose of this paper is to contribute to second language acquisition research by exploring the age effects in the initial stages of second language (L2) development with respect to the mother tongue transfer of morphosyntactic features. It assumes the generative framework of grammar and language acquisition, where direct $\mathrm{L} 2$ childadult comparison has been a neglected area of research. The $[ \pm$ strong] Infl parameter 
of Universal Grammar, V-raising in particular, is taken as the linguistic element of investigation, since it assigns different values in English [- strong] and in Macedonian [+ strong]. The participants in the experiment were a group of children (age 8-11) and a group of adults (age 20-60), all native speakers of Macedonian and beginners of $L 2$ English. They were tested after a four-week exposure to specifically designed instruction on English V-raising. As the entire L1 grammar transfers, the results offer support for the Conservation Hypothesis for L1 transfer for the initial stages of second language acquisition (Van de Craats et al. 1999).

KEYWORDS: age effects, language transfer, initial stages, second language acquisition of English, V-raising.

(Original scientific paper received 31.01.2013;

revised 14.07.2013;

accepted 18.09.2013) 